\title{
Association between Adipocytokines, Systemic Inflammation and 0xidative Stress Biomarkers among Obese Type 2 Diabetic Patients
}

\author{
Essam H. Jiffri* \\ Department of Medical Laboratory Technology, King Abdulaziz University, Saudi Arabia
}

Submission: May 01, 2017; Published: May 30, 2017

"Corresponding author: Essam H Al-Jiffri, Department of Medical Laboratory Technology, Faculty of Applied Medical Sciences, King Abdulaziz University, P.0. Box 80324, Jeddah, 21589, Saudi Arabia, Email: ejiff@hotmail.com

\begin{abstract}
Background: Type 2 diabetes mellitus (T2DM) is usually associated with microvascular and macrovascular complications because of abnormal level of inflammatory cytokines, adiopcytokines and oxidative stress biomarkers.

Objective: The aim of this study was to measure the degree of association between adipocytokines, systemic inflammation and oxidative stress biomarkers among obese type 2 diabetic patients. Material and Methods: One hundred non-smokers obese type 2 diabetic patients were included in this study, the mean age was $46.39 \pm 5.42$ year and mean body mass index was $32.48 \pm 3.26 \mathrm{~kg} / \mathrm{m} 2 . \mathrm{In}$ the other hand another one hundred non-diabetic subjects not suffering of any disease, were participated in the study as a control group, the mean age was $47.88 \pm 4.71$ year and mean body mass index was $26.52 \pm 2.17 \mathrm{~kg} / \mathrm{m} 2$.
\end{abstract}

Results: There were significant elevations in tumor necrosis factor- alpha (TNF- $\alpha$ ), interleukin-6 (IL-6), C-reactive protein (CRP), leptin, malondialdehyde (MDA) levels and significant decreases in adiponectin, GPX, GSH and SOD levels were detected among obese T2DM subject in addition, IL-6, TNF- $\alpha$, CRP and leptin showed a strong direct relationship with MDA and a strong inverse relationship with glutathione (GSH), (GPx) and superoxide dismutase (SOD). While, adiponectin showed an inverse relationship with IL-6, TNF- $\alpha$, CRP \& leptin and a strong inverse relationship with MDA $(\mathrm{P}<0.05)$.

Conclusion: The present study added more confirmations to closely link obesity with adipocytokines, systemic inflammation and enhanced oxidative stress biomarkers in obese T2DM.

Keywords: Adipocytokines; Cytokines; Obesity; Oxidative Stress; Type 2 Diabetes

\section{Introduction}

Type 2 diabetes mellitus (T2DM) accounts for more than $90 \%$ of those with diabetes [1]. According to World Health Organization (WHO), estimate that about 366 million people will have diabetes by year 2030 worldwide [2]. Risk cardiovascular disorders is 2-4 times more among T2DM than non-diabetic subjects [3] where about $80 \%$ of T2DM patientshave cardiovascular complications asperipheral arterial disease, stroke and heart disease [4]. Diabetes is a group of metabolic diseases that leads to impaired wound healing [5], higher susceptibility to infections [6] atherosclerosis [7], micro-and macrovascular alterations [8] even with optimal glycemic control [9], however poor diabetic control is usually associated with many co-morbidities due to systemic inflammation in T2DM patients [10-12].
Obesity is a state of increase mass of adipose tissue that is considered as active endocrine organ [13] which secretes inflammatory cytokines and adipocytokines that are involved in systemic and local regulation of several metabolic processes [14]. However, disturbed adipose tissue endocrine function in obesity is associated chronic low-grade systemic inflammation and facilitate development of obesity comorbidities as T2DM and vascular disorders [15].

Adipose tissue is the main source of cytokines as increased body fat mass is usually associated with high level of inflammatory cytokines such as C-reactive protein (CRP), tumor necrosis factor- alpha (TNF- $\alpha$ ) and interleukin-6 (IL-6) [16,17]. 
While, lymphocytes and macrophages produce low level of antiinflammatory interleukin-10 (IL-10) in T2DM patients [18] produces low-grade systemic inflammation [19] which play an important role in the pathogenesis of cardiovascular disorders [20-22] and insulin resistance [23-26].

Adiponectin is an adipocytokine that is inversely correlated to the degree of obesity $[27,28]$, which improve insulin sensitivity, and has an anti-inflammatory, antioxidant and anti-hypertensive effects [29-31] in addition to prevention of endothelial dysfunction [32]. In the other hand, leptin correlated to the degree of obesity [33]. Leptin is involved in food intake and energy expenditure modulation; however, obesity is associated with hyperleptinemia that means increased resistance to leptin that is associated with insulin resistance, hypertension and proatherogenic condition [33,34].

Oxidative stress considered the principle cause of micro- and macrovascular alterations among T2DM [35] due to excessive production of reactive oxygen species than the antioxidant capacity of the cells [36]. Several mechanisms can contribute to the systemic hyper-inflammatory status in diabetes, including dyslipidemia that modulates the function and activity of myeloid cells, and the increase of oxidative metabolism with enhanced production of reactive oxygen species (ROS) [37]. As a defense mechanism cells produce antioxidants (AOs) that prevent or limit oxidative tissue injury as overproduction of ROS may result in an imbalance between ROS and AOS leading to oxidative stress and tissue damage [38] by several mechanisms, including damage of DNA, lipid membranes peroxidation, enzymes oxidation and stimulation of pro-inflammatory cytokines [39].

The aim of this study was to measure the degree of association between adipocytokines, systemic inflammation and oxidative stress biomarkers among obese type 2 diabetic patients.

\section{Material and Methods}

\section{Subjects}

One hundred obese T2DM patients visiting king Abdulaziz University Hospital, Jeddah, Saudi Arabia, were included in this study, the mean age was $46.39 \pm 5.42$ year and mean body mass index was $32.48 \pm 3.26 \mathrm{~kg} / \mathrm{m}^{2}$. Initially, a physician at King Abdulaziz University Hospital examined all participants; their medical history was taken to collect information about general condition, physical activity and current medications if any. All subjects with any cardiovascular conditions (those with a known history of uncontrolled hypertension, congenital and rheumatic heart diseases), any pulmonary disease (obstructive or restrictive lung diseases), were excluded from the study. In the other hand one hundred non-diabetic subjects not suffering of any disease, were participated in the study as a control group, the mean age was $47.88 \pm 4.71$ year and mean body mass index was $26.52 \pm 2.17 \mathrm{~kg} / \mathrm{m}^{2}$. The Ethics Committee of the Faculty of Applied Medical Sciences, King Abdulaziz University, approved this study. All participants signed a written informed consent.

\section{Measurements}

In all subjects, clinical and anthropometric data were collected at the time of enrollment. Independent assessors who were blinded to group assignment and not involved in the routine treatment of the patients performed clinical evaluations and laboratory analysis. Body mass index (BMI) was calculated on the basis of weight (kilograms) and height (meters), and subjects were classified as normal weight (BMI $18.5-24.9 \mathrm{~kg} /$ $\mathrm{m}^{2}$ ), overweight (BMI $25-29.9 \mathrm{~kg} / \mathrm{m}^{2}$ ), and obese (BMI $\geq 30 \mathrm{~kg}$ / $\mathrm{m}^{2}$ ). In addition, between 07:30 and 09:00, after an overnight fast of $12 \mathrm{~h}$ fasting blood sample was drawn. Triglycerides, highdensity lipoprotein cholesterol (HDL-c) and plasma glucose concentration and insulin were determined (Roche Diagnostics $\mathrm{GmbH}$, Mannheim, Germany) using commercially available assay kits. Insulin resistance was assessed by homeostasis model assessment (HOMA-IR). HOMA-IR=[fasting blood glucose (mmol/l) fasting insulin (mIU/ml)]/22.5 [40].

A. Measurement of oxidative stress markers and antioxidant status: For all participants serum (from $10 \mathrm{ml}$ blood in plain vial) and plasma (from $5 \mathrm{ml}$ blood in EDTA vial) were separated from the sample within 30 min of collection and was stored in pyrogen free polypropylene cryo-tubes at $\left(-80{ }^{\circ} \mathrm{C}\right)$ until analysis. Assessment of lipid markers for peroxidation as malondialdehyde (MDA) were determined according to Buege and Aust. [41]. However, Anti-oxidant status, glutathione (GSH) that was determined by the method of Beutler and colleagues [42], in the other hand, glutathione peroxidase (GPX) and superoxide dismutase (SOD) were measured by the method of Nishikimi and colleagues [43].

B. Measurement of inflammatory cytokines and adipocytokines:Venous blood samples after a 12-hours fasting were centrifuged at $4{ }^{\circ} \mathrm{C}(1000 \mathrm{X}$ g for $10 \mathrm{~min})$. "Immulite 2000" immune-assay analyzer (Siemens Healthcare Diagnostics, Deerfield, USA) analyzed IL-6 level. However, TNF- $\alpha$ and CRP levels were measured by ELISA kits (R\&D, USA) by using ELISA technique (ELX 808; BioTek Instruments, USA).In addition, plasma sample with K2EDTA was collected after centrifugation and stored at -80 ${ }^{\circ} \mathrm{C}$ to analyze leptin and adiponectin with commercial kits (Randox).

\section{Statistical Analysis}

Independent " $\mathrm{t}$ " test was used to compare the investigated parameters between both groups $(\mathrm{P}<0.05)$. However, the degree of correlation between IL-6, TNF- $\alpha$, CRP, leptin, adiponectin, MDA, GPX, GSH and SOD was calculated with Pearson's correlation coefficients (r).

\section{Results}

Detailed baseline characteristics of the patients with T2DM subjects and non-diabetic subjects control presented in Table 1. There was a significant difference for all characteristics of the 
obese T2DM subjectsversus non-diabetic subjects, except in the age and gender (Table 1).

Table 1: Characteristics of the whole study population

\begin{tabular}{|c|c|c|c|}
\hline & \multicolumn{2}{|c|}{ Mean \pm SD } & \multirow[b]{2}{*}{ Significance } \\
\hline & $\begin{array}{c}\text { T2DM } \\
\text { subjects } \\
(n: 100)\end{array}$ & $\begin{array}{l}\text { Non-diabetic } \\
\text { subjects } \\
\text { (n:100) }\end{array}$ & \\
\hline Age (year) & $46.39 \pm 5.42$ & $47.88 \pm 4.71$ & $P>0.05$ \\
\hline $\begin{array}{l}\text { Gender (Male/ } \\
\text { Female) }\end{array}$ & $58 / 42$ & $55 / 45$ & $\mathrm{P}>0.05$ \\
\hline $\begin{array}{c}\text { Body mass } \\
\text { index }\left(\mathrm{kg} / \mathrm{m}^{2}\right)\end{array}$ & $32.48 \pm 3.26^{*}$ & $26.52 \pm 2.17$ & $P>0.05$ \\
\hline SBP (mm Hg) & $128.13 \pm 15.21 *$ & $117.23 \pm 10.42$ & $\mathrm{P}<0.05$ \\
\hline DBP (mm Hg) & $87.64 \pm 6.51^{*}$ & $79.92 \pm 5.11$ & $\mathrm{P}<0.05$ \\
\hline $\mathrm{TG} \quad(\mathrm{mg} / \mathrm{dl})$ & $225.19 \pm 43.12^{*}$ & $175.35 \pm 29.13$ & $\mathrm{P}<0.05$ \\
\hline HDL-c (mg/dl) & $41.32 \pm 5.18^{*}$ & $48.54 \pm 7.26$ & $\mathrm{P}<0.05$ \\
\hline $\begin{array}{l}\text { Fasting plasma } \\
\text { insulin }(\mathrm{U} / \mathrm{l})\end{array}$ & $11.42 \pm 3.14^{*}$ & $7.63 \pm 2.19$ & $\mathrm{P}<0.05$ \\
\hline $\begin{array}{l}\text { HOMA-IR } \\
\text { (unites) }\end{array}$ & $5.78 \pm 2.53^{*}$ & $1.92 \pm 0.85$ & $\mathrm{P}<0.05$ \\
\hline $\begin{array}{l}\text { Fasting plasma } \\
\text { glucose (mg/ } \\
\text { dl) }\end{array}$ & $192.27 \pm 24.17^{*}$ & $83.38 \pm 7.96$ & $\mathrm{P}<0.05$ \\
\hline
\end{tabular}

SBP: Systolic blood pressure; DBP: Diastolic blood pressure; TG: Triglyceride; HDL-c: High-density lipoprotein cholesterol; HOMA-IR: Homeostasis Model Assessment-Insulin Resistance Index; ${ }^{*}$ Significant level $(p<0.05)$.

However, there were significant elevations in IL-6, TNF- $\alpha$, CRP, leptin, MDA levels and significant decreases in adiponectin, GPX, GSH and SOD levels were detected among T2DM obese subjects (Table 2).

Table 2: The mean value and the significance values of different parameters in both groups

\begin{tabular}{|c|c|c|c|}
\hline & \multicolumn{2}{|c|}{ Mean \pm SD } & \multirow{2}{*}{ Significance } \\
\hline & $\begin{array}{c}\text { T2DM } \\
\text { subjects }\end{array}$ & $\begin{array}{l}\text { Non-diabetic } \\
\text { subjects }\end{array}$ & \\
\hline TNF- $\alpha(\mathrm{pg} / \mathrm{mL})$ & $12.35 \pm 2.57^{*}$ & $8.45 \pm 2.16$ & $\mathrm{P}<0.05$ \\
\hline IL-6 (pg/mL) & $6.14 \pm 1.73^{*}$ & $3.69 \pm 1.35$ & $\mathrm{P}<0.05$ \\
\hline CRP (mg/L) & $4.87 \pm 1.45^{*}$ & $2.33 \pm 1.12$ & $\mathrm{P}<0.05$ \\
\hline Leptin (ng/ml) & $16.23 \pm 4.84^{*}$ & $8.71 \pm 2.95$ & $\mathrm{P}<0.05$ \\
\hline $\begin{array}{l}\text { Adiponectin (mg/ } \\
\mathrm{ml} \text { ) }\end{array}$ & $9.88 \pm 3.56^{*}$ & $13.16 \pm 3.82$ & $\mathrm{P}<0.05$ \\
\hline MDA (mmol/L) & $26.52 \pm 7.11^{*}$ & $18.49 \pm 5.13$ & $\mathrm{P}<0.05$ \\
\hline GPx (units/gHb) & $20.19 \pm 5.23^{*}$ & $27.78 \pm 6.28$ & $\mathrm{P}<0.05$ \\
\hline SOD (units/mL) & $41.27 \pm 8.15^{*}$ & $54.12 \pm 10.15$ & $\mathrm{P}<0.05$ \\
\hline $\mathrm{GSH}(\mathrm{mmol} / \mathrm{gHb})$ & $\begin{array}{c}2113.48 \pm \\
147.29^{*}\end{array}$ & $2412.54 \pm 182.31$ & $\mathrm{P}<0.05$ \\
\hline
\end{tabular}

BMI: Body mass index; TNF- $\alpha$ : tumor necrosis factor - alpha; IL-6: Interleukin-6; CRP: C- reactive protein; CD: conjugated dienes; MDA Malondialdehyde; GPx: Glutathione peroxidase; SOD: Superoxide dismutase; GSH: Glutathione; *Significant level $(p<0.05)$.
The IL-6, TNF- $\alpha$, CRP and leptin showed a strong direct relationship with MDA and a strong inverse relationship with GPX, GSH and SOD. While, adiponectin showed an inverse relationship with IL-6, TNF- $\alpha$, CRP \& leptin and a strong inverse relationship with MDA in obese T2DM subjects (Table 3$)(\mathrm{P}<0.05)$.

Table 3: Correlation coefficient ( $r$ ) of IL-6, TNF- $\alpha$, CRP, leptin, adiponectin, MDA, GPX, GSH and SOD of obese T2DM subjects.

\begin{tabular}{|c|c|c|c|c|}
\hline & $\begin{array}{c}\text { MDA } \\
\text { (mmol/L) }\end{array}$ & $\begin{array}{c}\text { GPx } \\
\text { (units/ } \\
\text { gHb) }\end{array}$ & $\begin{array}{c}\text { SOD } \\
\text { (units/ } \\
\mathbf{m L} \text { ) }\end{array}$ & $\begin{array}{c}\text { GSH } \\
\text { (mmol/ } \\
\mathbf{g H b})\end{array}$ \\
\hline TNF- $\alpha(\mathrm{pg} / \mathrm{mL})$ & $0.754^{*}$ & $-0.713^{* *}$ & $-0.727^{* *}$ & $-0.582^{*}$ \\
\hline IL-6 (pg/mL) & $0.628^{* *}$ & $-0.649^{* *}$ & $-0.644^{* *}$ & $-0.818^{* *}$ \\
\hline $\mathrm{CRP}(\mathrm{mg} / \mathrm{L})$ & $0.631^{* *}$ & $-0.615^{* *}$ & $-0.639^{* *}$ & $-0.825^{* *}$ \\
\hline Leptin $(\mathrm{ng} / \mathrm{ml})$ & $0.713^{* *}$ & $-0.516^{*}$ & $-0.526^{*}$ & $-0.61^{*}$ \\
\hline $\begin{array}{c}\text { Adiponectin(mg/ } \\
\mathrm{ml})\end{array}$ & $-0.512^{*}$ & $0.627^{* *}$ & $0.654^{* *}$ & $0.529^{*}$ \\
\hline
\end{tabular}

Spearman's correlation was used *: $\mathrm{P}<0.05^{\star *}: \mathrm{P}<0.01$

\section{Discussion}

Currently, T2DMis the most prevalent metabolic disorder worldwide [44], which is related to vascular problems $[45,46]$. The main finding of our study was significant elevations in IL6 , TNF- $\alpha$, CRP, leptin, MDA levels and significant decreases in adiponectin, GPX, GSH and SOD levels were detected among obese T2DM subjects in addition, IL-6, TNF- $\alpha$, CRP and leptin showed a strong direct relationship with MDA and a strong inverse relationship with GPX, GSH and SOD. While, adiponectin showed an inverse relationship with IL-6, TNF- $\alpha$, CRP \& leptin and a strong inverse relationship with MDA $(\mathrm{P}<0.05)$. Our present investigation added more confirmations to closely link obesity with adipocytokines, systemic inflammation and enhanced oxidative stress biomarkers in T2DM.

Firstly, levels of MDA as a biomarker for oxidative stress were elevated, depletion in GPXand GSH levels along with extreme inhibition of SOD activityin obese T2DM, these results are in line with many previous studies.

Ustundag et al. [47] found an increase in the concentration of MDA in obese group as compared with the control group. In addition, Condoner-Franch et al. [48] showed that, erythrocyte of obese patients had higher MDA and lower GSH concentrations than healthy subjects. However, Al-Menabbawy et al. [49] stated that significant low levels of SOD enzyme was detected among obese adolescents as compared with control group. While, Habib et al. [50] enrolled 72 obese subjects of both sexes and 40 non-obese subjects, their age ranged between 5-17 years , they found significant increased levels of TNF-a, IL-6, leptin, MDA and fasting blood sugar and significant reduction in GSH and SOD activity were detected among obese individuals as compared with control group. Also, Codoñer-Franch et al. [51] stated that Nitric oxide (NO) production increased among 60 obese children associated with increased metabolic risk factors included insulin resistance index, serum lipid profile and blood 
pressure correlated with abdominal obesity, inflammatory markers and oxidative stress markers. Similarly, Hirao et al. [52] confirmed that abdominalobesity is associated with production of increasedreactiveoxygenspecies among 96 Japanese male diabetic patients. Moreover, de Souza Bastos et al. [53] enrolled 100 subjects with diabetes and divided them according to dyslipidemic and diabetic status and they found that diabetics presented significantly higher levels of MDA, IL-6 and TNF- $\alpha$, however subjects with normal blood glucose level and dyslipidemia presented significantly high levels of IL- 6 and TNF- $\alpha$ when compared subjects with normal blood glucose level without dyslipidemia, in addition, presence of DM complications positively correlated with MDA levels.

Excessive adiposity produces oxidative stress via several mechanisms. Firstly peroxisomal and mitochondrial oxidation of fatty acids produce ROS. Secondly, mitochondrial respiratory chain generates free radicals by over-consumption of oxygen associated with mitochondrial oxidative phosphorylation along with generating ROS. By lipid-rich diets that may alter oxygen metabolism in addition to diminished antioxidant enzymes activity [54]. Moreover, obesity is characterized with excessive storage of energy in adipocytes because of energy imbalance which lead to hyperplasia and hypertrophy of adipocytes which in turn induce oxidative stress by adipocytescorrelated inflammatory macrophages. Based on the above, there is a close link among obesity and oxidative stress [55].

Secondly, levels of leptin, TNF- $\alpha$, IL-6 and CRP were increased and level of adiponectin in obese T2DM subjects in the present study as compared with non-diabetic subjects. Moreover, because adipokines induce the production of ROS generating oxidative stress, we can suggest that adipocytokines elevation is one of the main causes for the obtained high obesityinduced oxidative stress. These obtained results strongly suggest that obese T2DMpatients are more susceptible to persistence of inflammation and to development of obesity-related complications that involve oxidative stress in their pathogenesis especially cardiovascular complications. Our present findings confirm that of Fernandez-Real et al. [56] \& Kern et al. [57] who showed that increased IL- 6 in obesity increased the risk for cardiovascular complications. Ottobelli et al. [58] proved that levels of adipocytokines included adiponectin and resistin were reduced, markers of inflammation included CRP, IL-6, adenosine deaminase (ADA) and dipeptidyl peptidase-IV (DPP-IV) activities were increased and levels of oxidative stress included MDA and ferric reducing antioxidant power - FRAP were increased among 68 obese subjects. Indulekha and colleagues stated that increased visceral fat level was associated with impaired glucose tolerance, reduced serum adiponectin along with increased TNF- $\alpha$, CRP, HOMA-IR and visfatin among 49 subjects with impaired glucose tolerance and 93 subjects with T2DM [59]. Upon all, we strongly support the above mentioned mechanisms for excessive oxidative stress induction in obesity. It is established now that free radicals can cause DNA-protein damage. Therefore, we can expect more lipid peroxidation and protein damage including hemoglobin, DNA and protein in the body fluids and tissues of obese T2DM. Hence, the reduction in SOD activity and in GSH level along with persistent elevation in MDA levels in the current study may create oxidant conditions that favor the development of co-morbid diseases sooner.

\section{Conclusion}

The present study added more confirmations to closely link T2DM with adipocytokines, systemic inflammation and enhanced oxidative stress biomarkers.

\section{References}

1. Taher M, Nassir E (2011) Beneficial effects of clopidogrel on glycemic indices and oxidative stress in patients with type 2 diabetes. Saudi Pharmaceutical Journal 19(2): 107-113.

2. Li R, Lu W, Jiang QW, Li YY, Zhao GM, et al. (2012) Increasing prevalence of Type 2 diabetes in Chinese adults in Shanghai. Diabetes Care 35(5): 1028-30.

3. Stamler J, Vaccaro O, Neaton JD, Wentworth D (1993) Diabetes, other risk factors, and 12-yr cardiovascular mortality for men screened in the Multiple Risk Factor Intervention Trial. Diabetes Care 16: 434-444.

4. http://www.cdc.gov/diabetes/pubs/pdf/ndfs_2005.pdf

5. Goova MT, Li J, Kislinger T, Qu W, Lu Y, et al. (2001) Blockade of receptor for advanced glycation end-products restores effective wound healing in diabetic mice. The American Journal of Pathology 159: 513-525.

6. Hirsch T, Spielmann M, Zuhaili B, Koehler T, Fossum M, et al. (2008) Enhanced susceptibility to infections in a diabetic wound healing model. BMC Surgery 8: 5 .

7. Halliwell B (2000) Oral inflammation and reactive species: A missed opportunity? Oral Diseases 6: 136-137.

8. Mooradian AD (2009) Dyslipidemia in type 2 diabetes mellitus. Nature Clinical Practice. Endocrinology \& Metabolism 5: 150-159.

9. Chello M, Spadaccio C, Lusini M, Covino E, Blarzino C, et al. (2009) Advanced glycation end products in diabetic patients with optimized glycaemic control and their effects on endothelial reactivity: Possible implications in venous graft failure. Diabetes Metab Res Rev 25(5): 420-426.

10. Mirza S, Hossain M, Mathews C, Martinez P, Pino P, et al. (2012) Type 2 - diabetes is associated with elevated levels of TNF-alpha, IL-6 and adiponectin and low levels of leptin in a population of Mexican Americans: A cross-sectional study. Cytokine 57: 136-142.

11. Vinik, AI (2005) The metabolic basis of atherogenic dyslipidemia. Clinical Cornerstone 7: 27-35.

12. Pickup JC, Chusney GD, Thomas SM, BurtD (2000) Plasma interleukin-6, tumour necrosis factor alpha and blood cytokine production in type 2 diabetes. Life Sciences 67(3): 291-300.

13. DeFronzo RA (2010) Insulin resistance, lipotoxicity, type 2 diabetes and atherosclerosis: the missing links. The Claude Bernard Lecture 2009. Diabetologia 53(7): 1270-1287.

14. Greenberg AS, Obin MS (2006) Obesity and the role of adipose tissue in inflammation and metabolism. Am J Clin Nutr 83(2): 461S-465S.

15. Murdolo G, Smith U (2006) The dysregulated adipose tissue: a connecting link between insulin resistance, type 2 diabetes mellitus and atherosclerosis. Nutr Metab Cardiovasc Dis 16(Suppl 1): S35-S38. 
16. Carvalho MHC, Colac o AL, Fortes ZB (2012) Citocinas Disfunc,a a Endotelial e Resiste^ncia a`Insulina. Arq Bras Endocrinol Metab 50(2): 304-312.

17. Dandona P, Aljada A, Bandyopadhyay A (2004) Inflammation: the link between insulin resistance, obesity and diabetes. Trends Immunol 25(1): 4-7.

18. Exel EV, Gussekloo J, Craen AJM, Frolich M, Wiel AB, et al. (2002) Low production capacity of interleukin-10 associates with the metabolic syndrome and Type 2 diabetes. Diabetes 51(4): 1088-1092.

19. Petersen AM, Pedersen BK (2005) The anti-inflammatory effect of exercise. J Applied Physiol 98: 1154-1162.

20. Dobrin JS, Lebeche D (2010) Diabetic cardiomyopathy: signaling defects and therapeutic approaches. Expert Rev Cardiovasc Ther 8(3): 373-391.

21. Opie LH, Yellon DM, Gersh BJ (2011) Controversies in the cardiovascular management of type 2 diabetes. Heart 97(1): 6-14.

22. Singh S, Dhingra S, Ramdath DD, Vasdev S, Gill V, et al. (2010) Risk factors preceding type 2 diabetes and cardiomyopathy. J Cardiovasc Transl Res 3(5): 580-596.

23. Vaarala O, Yki-Jarvinen H (2012) Diabetes: should we treat infection or inflammation to prevent T2DM? Nature Reviews. Endocrinology 8: 323-325.

24. Herder C, Karakas M, Koenig W (2011) Biomarkers for the prediction of type 2 diabetes and cardiovascular disease. Clin Pharmacol Ther 90 52-66.

25. Marchant DJ, Boyd JH, Lin DC, Granville DJ, Garmaroudi FS, et al. (2010) Inflammation in myocardial diseases. Circ Res 110(1): 126-144.

26. Taube A, Schlich R, Sell H, Eckardt K, Eckel J (2012) Inflammation and metabolic dysfunction: links to cardiovascular diseases. Am J Physiol Heart Circ Physiol 302(11): H2148-H2165.

27. Okamoto Y, Kihara S, Funahashi T, Matsuzawa Y, Libby P (2004) Adiponectin: a key adipocytokine in metabolic syndrome. Clin Sci (Lond) 110: 267-278.

28. Hotta K, Funahashi T, Arita Y, Takahashi M, Matsuda M, et al. (2000) Plasma concentrations of a novel, adipose-specific protein, adiponectin, in type 2 diabetic patients. Arterioscler Thromb Vasc Biol 20: 15951599.

29. Jalovaara K, Santaniemi M, Timonen M, Jokelainen J, Kesaniemi YA, et al. (2008) Low serum adiponectin level as a predictor of impaired glucose regulation and type 2 diabetes mellitus in a middle-aged Finnish population. Metabolism 57: 1130-1104.

30. Chow WS, Cheung BM, Tso AW, Xu A, Wat NM, et al. (2007) Hypoadiponectinemia as a predictor for the development of hypertension: a 5-year prospective study. Hypertension 49: 14551461.

31. Tilg H, Moschen AR (2008) Role of adiponectin and PBEF/visfatin as regulators of inflammation: involvement in obesityassociated diseases. Clin Sci (Lond) 114: 275-288.

32. Antoniades C, Antonopoulos AS, Tousoulis D, Stefanadis C (2009) Adiponectin: from obesity to cardiovascular disease. Obes Rev 10(3): 269-279.

33. Havel PJ (200) Role of adipose tissue in body-weight regulation: mechanisms regulating leptin production and energy balance. Proc Nutr Soc 59(3): 359-371.

34. Correia ML, Rahmouni K (2006) Role of leptin in the cardiovascular and endocrine complications of metabolic syndrome. Diabetes Obes Metab 8: 603-610.
35. Unger J (2008) Reducing Oxidative Stress in Patients with Type 2 Diabetes Mellitus: A Primary Care Call to Action. Insulin 3: 176-184.

36. Brownlee M (2001) Biochemistry and molecular cell biology of diabetic complications. Nature 414(6865): 813-820.

37. Millar TM, Phan V, Tibbles LA (2007) ROS generation in endothelial hypoxia and reoxygenation stimulates MAP kinase signaling and kinase-dependent neutrophil recruitment. Free Radical Biology \& Medicine 42(8): 1165-1177.

38. Chapple, IL, \& Matthews, JB (2007) The role of reactive oxygen and antioxidant species in periodontal tissue destruction. Periodontology 2000(43): 160-232.

39. Li J, Huang M, Shen X (2014) The association of oxidative stress and proinflammatory cytokines in diabetic patients with hyperglycemic crisis. Journal of Diabetes and its Complications 28(5): 662-666.

40. Matthews DR, Hosker JP, Rudenski AS, Naylor BA, Treacher DF, et al. (1985) Homeostasis model assessment: insulin resistance and beta cell function from plasma FBS and insulin concentrations in man. Diabetologia 28: 412-419.

41. Buege JA, Aust SD (1978) Microsomal lipid peroxidation. Methods Enzymol 52: 302-310.

42. Beutler E, Duron O, Kelly BM (1963) Improved method for the determination of blood glutathione. J Lab Clin Med 61: 882-888.

43. Nishikimi M, Appaji Rao N, Yagi K (1972) The occurrence of superoxide anion in the reaction of reduced phenazine methosulfate and molecular oxygen. Biochem Biophys Res Commun 46: 849-854.

44. Donath MY, Shoelson SE (2011) Type 2 diabetes as an inflammatory disease. Nat Rev Immunol 11: 98-107.

45. Avogaro A, Albiero M, Menegazzo L, de Kreutzenberg S, Fadini GP (2011) Endothelial dysfunction in diabetes: the role of reparatory mechanisms. Diabetes Care 34 (Suppl 2): S285-290.

46. Ding H, Triggle CR (2010) Endothelial dysfunction in diabetes: multiple targets for treatment. Pflugers Arch 459(6): 977-994.

47. Ustundag B, Gungor S, Aygün AD, Turgut M, Yilmaz E (2007) Oxidative status and serum leptin levels in obese prepubertal children. Cell Biochem Funct 25(5): 479-83.

48. Codoñer-Franch P, Boix-Garci'a L, Simo' -Jorda' R, Del CastilloVillaescusa C, Maset-Maldonado J, et al. (2010) Is obesity associated with oxidative stress in children? Int J Pediatr Obes 5(1): 56-63.

49. Al-Menabbawy K, Sallam M, Taha S, Mottawie H, Ibrahiem A (2006) Obesity, sedentary lifestyle and oxidative stress among young adolescent. J Med Sci 6(6): 956-9661.

50. Habib SA, Saad EA, Elsharkawy AA, Attia ZR (2015) Pro-inflammatory adipocytokines, oxidative stress, insulin, $\mathrm{Zn}$ and $\mathrm{Cu}$ : Interrelations with obesity in Egyptian non-diabetic obese children and adolescents. Adv Med Sci 60(2): 179-185.

51. Codoñer-Franch P, Tavárez-Alonso S, Murria-Estal R, Megías-Vericat J, Tortajada-Girbés M, et al. (2011) Nitric oxide production is increased in severely obese children and related to markers of oxidative stress and inflammation. Atherosclerosis 215(2): 475-480.

52. Hirao K, Maruyama T, Ohno Y, Hirose H, Shimada A, et al. (2010) Association of increased reactive oxygen species production with abdominal obesity in type 2 diabetes. Obes Res Clin Pract 4(2): e83-e162.

53. de Souza Bastos A, Graves DT, de Melo Loureiro AP, Júnior CR, Corbi SC, et al. (2016) Diabetes and increased lipid peroxidation are associated with systemic inflammation even in well-controlled patients. J Diabetes Complications 30(8): 1593-1599. 
54. Ferna'ndez-Sa'nchez A, Madrigal-Santilla'n E, Bautista M, Esquivel-Soto J, Mor-ales-Gonza' lez A, Esquivel-Chirino C, et al. (2011) Inflammation, oxidative stress, and obesity. Int J Mol Sci 12(5): 3117-332.

55. Codoñer-Franch P, Valls-Belle' s V, Arilla-Codoñer A, Alonso-Iglesias E (2011) Oxidant mechanisms in childhood obesity: the link between inflammation and oxida-tive stress. Transl Res 158(6): 369-84.

56. Fernandez-Real JM, Vayreda M, Richart C, Gutierrez C, Broch M, et al. (2001) Circulating interleukin 6 levels, blood pressure and insulin sensitivity in appar- ently healthy men and women. J Clin Endocrinol Metab 86(3): 1154-1159.

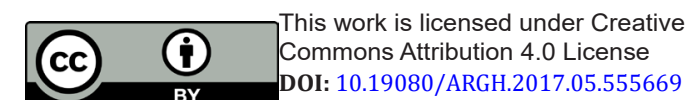

57. Kern PA, Ranganathan S, Li C, Wood L, Ranganathan G (2011) Adipose tissue tumor necrosis factor and interleukin-6 expression in human obesity and insulin resistance. Am J Physiol 280: 745-751.

58. Ottobelli Chielle E, de Souza WM, da Silva TP, Moresco RN, Moretto MB (2016) Adipocytokines, inflammatory and oxidative stress markers of clinical relevance altered in young overweight/obese subjects. Clin Biochem 49(7-8): 548-553.

59. Indulekha K, Anjana RM, Surendar J, Mohan V (2011) Association of visceral and subcutaneous fat with glucose intolerance, insulin resistance, adipocytokines and inflammatory markers in Asian Indians (CURES-113). Clin Biochem 44(4): 281-287.

\section{Your next submission with JuniperPublishers will reach you the below assets}

- Quality Editorial service

- Swift Peer Review

- Reprints availability

- E-prints Service

- Manuscript Podcast for convenient understanding

- Global attainment for your research

- Manuscript accessibility in different formats

( Pdf, E-pub, Full Text, audio)

- Unceasing customer service

Track the below URL for one-step submission https://juniperpublishers.com/online-submission.php 